This item was submitted to Loughborough's Research Repository by the author.

Items in Figshare are protected by copyright, with all rights reserved, unless otherwise indicated.

\title{
Shaping geographies of informal education: a global South perspective
}

PLEASE CITE THE PUBLISHED VERSION

https://doi.org/10.1080/24694452.2019.1602466

\section{PUBLISHER}

Taylor \& Francis (Routledge) @ American Association of Geographers

\section{VERSION}

AM (Accepted Manuscript)

\section{PUBLISHER STATEMENT}

This is an Accepted Manuscript of an article published by Taylor \& Francis in Annals of the American Association of Geographers on 10 June 2019, available online: http://www.tandfonline.com/10.1080/24694452.2019.1602466.

\section{LICENCE}

CC BY-NC-ND 4.0

\section{REPOSITORY RECORD}

Gough, Katherine, Thilde Langevang, Paul W.K. Yankson, and George Owusu. 2019. "Shaping Geographies of Informal Education: A Global South Perspective". Loughborough University.

https://hdl.handle.net/2134/37812. 


\section{Shaping geographies of informal education: a global South perspective}

Katherine V. Gough, Geography and Environment, School of Social Sciences, Loughborough University, Loughborough LE113TU, UK k.v.gough@lboro.ac.uk

Thilde Langevang, Department of Management, Society and Communication, Copenhagen Business School, Copenhagen, Denmark tla@msc.cbs.dk

Paul W.K. Yankson, Department of Geography and Resource Development, University of Ghana pyankson@ug.edu.gh

George Owusu, Institute of Statistical, Social and Economic Research (ISSER)/Centre for Urban Management Studies (CUMS), University of Ghana gowusu@ug.edu.gh 


\begin{abstract}
This paper aims to shape understandings of the geographies of informal education by exploring an aspect of education that has been broadly overlooked by geographers to date apprenticeships - within a global South context. Drawing on qualitative research conducted in Accra, Ghana, where young male and female apprentices learn a trade alongside master craftspeople, the nature of the apprenticeship system and how it is evolving are explored. The paper develops an analytical framework for examining the dynamics of informal education with three core elements: the people and everyday praxes; the materialities, technologies, and spatialities of the learning process; and the regulatory apparatus. The apprenticeship system in Ghana is shown to be constantly evolving, with some aspects of the learning process remaining informal, some being formalized, whilst others are informalised, the extent and nature of these processes varying between trades and over time. The paper thus demonstrates how the boundary between informal and formal education is far from clear-cut, with processes of informalisation and formalization occurring concomitantly. Calls are made to expand the agenda of geographies of informal education in both the global North and South to incorporate livelihood-related issues, including apprenticeships, and geographers are challenged to rethink the informal/formal education divide within education. This timely research thus forms part of broader trends to consider how addressing the global South forces a rethinking and revisioning of theoretical frameworks.
\end{abstract}

Keywords: apprenticeship, education, informal, Ghana, Africa

\title{
Introduction
}

Geographies of education have evolved over the past decade to become an emerging subdiscipline making important contributions to our understanding of the "recursive production of education, space and society" (Pini et al. 2017, 13). Several reviews of the field (Collins and Coleman 2008; Hanson Thiem 2009; Holloway and Jöns 2012) and special issues (McCreary, Basu and Godlewska 2013; Mills and Kraftl 2016; Pini et al. 2017) have highlighted the diversity of topics and approaches that fall within the subdiscipline. The majority of studies, however, have focused on mainstream education in the global North, which has shaped the ways in which we view and conceptualize spaces of education. Calls have been made for geographies of education to become more spatially diverse by studying other spaces of education and by being more global in their scope (Holloway et al. 2010). Recent publications on alternative education spaces (Kraftl 2013a, 2013b, 2014) and informal education (Mills and Kraftl 2014), highlight how geographers have begun to respond to these calls, making important contributions to our understanding of education outside of the mainstream. But what picture of informal education emerges when we give priority to Southern experiences (cf. Connell 2007)?

This paper aims to shape understandings of the geographies of informal education by exploring an aspect of education that has been broadly overlooked by geographers to date apprenticeships - within a global South context. In recent years, apprenticeships have featured in policy agendas in both the global North and South as "introducing", "modernizing", "upgrading" or "formalizing" apprenticeships are seen as ways to react to the 
mounting youth unemployment crisis and ease school to work transitions (Fuller and Unwin 2009; Palmer 2009; Busso et al. 2017). Moreover, scholars in other disciplines have studied apprenticeships (see, for example, special issues of Journal of Vocational Education and Training eds Fuller and Unwin 2011, and Journal of Education and Training ed. Smith 2016), including within a West African context (see among others, Peil 1970; Obidi 1995; Argenti 2002; Palmer 2007, 2009; Jaarsma et al. 2011; Aryeetey et al. 2013). As Patchett $(2017,31)$ claims, however, despite geographers having "long demonstrated an interest in charting the geographical and bodily dynamics of work and employment ... very little attention has been paid to apprenticeships". This is an unfortunate oversight since apprenticeships have long been one of the chief sources of skill formation and technological change across the globe. As geographers, we have the potential to make important contributions to understanding apprenticeships by investigating how they vary within and across a range of contexts at different spatial and temporal scales, and in so doing challenge humanistic conceptions of learning, which have dominated the primarily anthropological literature.

Drawing on qualitative research conducted in Accra, Ghana, where young male and female apprentices learn a trade alongside master craftspeople, the following key questions are addressed: Who is involved in informal education and what characterizes the learning process? How do the changing materialities, technologies and spatialities of learning affect informal education? In which ways are informal education spaces connected to and regulated by formal spaces? The paper draws on rich empirical data from a study of four quite different trades - dressmaking, hairdressing, cane weaving and auto-repairs - highlighting the complexity and diversity of the apprenticeship system in Ghana.

Our analysis of apprenticeships in a global South context resonates beyond the geographical focus of this study, raising a number of important issues with implications for widening understandings of informal education and for the burgeoning work on geographies of education. First, we demonstrate the importance of bringing regulatory institutions into an analytical framework for studying informal education that also includes analyses of people, everyday praxes, power relations, materialities, technologies and spatialities. Second, we show how some elements of the apprenticeship system are being formalized while others remain informal and some are even informalising, the extent and nature of these processes varying between trades and over time. This highlights the blurred distinction between formality and informality, and the extensive links between the two, which have been widely rehearsed in debates on employment in the global South (Meagher 1995; Potts 2008) but overlooked in an educational context. Third, we highlight how informal education is important for generating meaningful livelihoods, indicating the need to expand the current cultural geographical focus of research on informal education emanating from the global North. This timely research thus forms part of broader trends to consider how addressing the global South forces a rethinking and revisioning of theoretical frameworks (Parnell and Robinson 2012; Lemanski 2014), linked to attempts to decolonize the discipline (Esson et al. 2017; Radcliffe 2017).

\section{Conceptualizing informal education}

Informal education - a form of learning that occurs in and through everyday life - has long been recognized as playing an important role in young people's learning, as well as their wider socialization (Mills and Kraftl 2014). Recent research by geographers has contributed 
to these discussions through studies focusing on informal learning within the school environment (Cartwright 2012; Sadlier 2014) and in an array of leisure spaces such as Scout Camps, the Boys Brigade and music rehearsal spaces etc. (Bannister 2014; Dickens and Lonie 2014; Kyle 2014; Mills 2015; Mills 2016). These studies have been predominantly undertaken in a global North context and mostly adopt a cultural geographical lens focusing on learning related to citizenship, consciousness raising, empowerment, personal development, empathy and other "soft skills". Limited attention has been directed by geographers to informal education spaces where livelihood related skills are learnt, such as work places; a notable exception is Aufseeser's (2014) study of informal learning by street children, which highlights how work can be a key site of learning for young people.

Despite having varied forms, there are some key characteristics of informal education, which set it apart from formal education (Smith and Phillips 2017). First, informal education typically denotes bodily learning and the acquisition of skills through observation, whereas formal education tends to focus more on theoretical and abstract learning via oral or written forms. Second, in contrast to formal education, informal education is portrayed as not connected to a particular place or institution (such as school/university), not being institutionalized through fixed curricular and the provision of certification, and not instigated by the state. Third, informal education is identified less with reproducing wider societal norms regarding expected knowledge but rather as belonging to more localized communities, making it "less conservative and more flexible, serving the learners better" (Smith and Phillips 2017, 70). Moreover, informal education is often portrayed as stemming from young people's motivation to "belong" to certain communities of practice (Smith and Phillips 2017), with young people assumed to opt in willingly because of genuine interest and a desire to learn (Mills and Kraftl 2014). As we show in this paper, these key characteristics do not necessarily hold in a global South context, and overlook the importance of informal education in relation to livelihoods and the role of power relations. This highlights the need for a rethinking of geographies of informal education away from one that is exclusively global North focused to a conceptualisation that is informed by Southern experiences (Connell 2007).

The focus of this paper is on apprenticeships, which typically involve work-based learning in an informal education setting. Apprenticeship as a model of learning forms a key part of the vocational education and training systems of many countries, and has been drawn on to inform theories of learning (Lave and Wenger 1991). The term "apprenticeship" is often used metaphorically to denote "the journey that an individual takes in order to acquire the specific disciplinary and vocational knowledge, applied skills, values and processes/rules associated with a particular occupation (in essence, an occupational identity)" (Fuller and Unwin 2009, 405). The term is also recognized internationally as a framework for skills formation "based on a set of reciprocal rights and obligations between employer and trainee which are set out in an agreement or contract" (Gospel and Fuller 1998, cited in Fuller and Unwin 2009).

While apprenticeships are often conceived of as being rigid, authoritarian and inflexible, there is a growing body of literature, which shows that they are much more fluid and geographically dynamic and diverse than is generally understood (Patchett 2017). Many different types of apprenticeships and ways of organizing them exist, and apprenticeship systems evolve over time in response to a range of processes. As Fuller and Unwin (2011, 262) argue, "the concept of apprenticeship is being stretched in different ways in response to social, political and economic challenges, some of which come from within the countries 
themselves, whilst others bear down from the supra-national level and reflect the pressures of globalization and the current crisis in global capital".

As a system involving work-based learning, often operating beyond the regulatory state apparatus, apprenticeships are typically categorized as an informal system of learning that is "embedded in a social network of informal customs, rules and enforcement mechanisms" (Schraven et al. 2013, 3). As Fuller and Unwin $(1998,158)$ argue, however, the distinction between formal and informal education is often problematic "because it implies the superiority of learning which takes place within educational institutions over, and distinct from, that which occurs in settings such as the workplace". This paper shows how apprenticeship systems exhibit different degrees of formalization, are regulated by governments and other actors to varying degrees, and have differing links to formal educational institutions.

In the global South, the term "informal apprenticeship" is often used to describe the system by which an apprentice acquires the skills for a trade or craft in a micro or small enterprise, learning and working alongside an experienced practitioner. The terminology used is not uniform, however, with terms such as "traditional apprenticeship" and "apprenticeship in the informal economy" also found. Despite these variances, it is widely recognized that informal education through apprenticeships is a prominent means for young people to acquire skills across the global South, particularly in countries with large informal economies. This is the case in West African countries where a body of literature has explored a range of aspects of apprenticeships including: motivations (Aryeetey, Doh and Andoh 2013), skills acquisition and learning the trade (Peil 1970, Obidi 1995, Frazer 2006, Palmer 2007, Schraven et al. 2013), materiality (Wallaert-Pêtre 2001, Jaarsma et al. 2011), power relations (Argenti 2002), organization of trades (Lloyd 1953), preparation for work (Haan and Serrière 2002, Hanson 2005, Ahadzie 2009), non-completion (Donkor 2012), and policies to support apprenticeships (Fluitman 1992, Palmer 2009). This paper adds new perspectives to the West African literature by adopting an original analytical framework that brings these various aspects together and illustrates how the changes identifited differ between trades and over time.

Inspired by the approach adopted by Mills and Kraftl (2014) in their key text on informal education, we develop a three-pronged analytical framework to capture the dynamics, complexities and practices of informal education, shaped by experiences from the global South. First, we focus on the people and everyday praxes involved in informal education, i.e. the (young) trainees, practitioners and educators "that literally 'do', 'enable' or 'facilitate' informal education" (Mills and Kraftl 2014, 11) and how they do it. This involves examining the motivations, experiences, challenges and aspirations of both educators and learners, the power relations between the various actors involved, and how these impact on the learning process. Second, a focus on the materialities, technologies and spatialities of the learning environment directs attention to the physical elements that enable the learning to take place. By examining the physical layout of the learning environment (Jaarsma et al. 2011), as well as the material practices and technologies used (Mills and Kraftl 2014), we incorporate a spatial element into the analysis. Third, diverging from Mills and Kraftl (2014) who emphasize the political motivation that drives informal education, we emphasize the role of the regulatory apparatus of informal learning and the importance of charting the institutional framework surrounding the learning process. This involves illuminating how informal learning spaces are impacted by, interact with, and are connected to formal institutions and formal learning spaces. 
Through adopting this three-pronged analytical framework, we illustrate the ways in which the three dimensions are closely interlinked and change over time. By analyzing how informal education varies over space and time, we show how informal learning spaces evolve in response to both local and global processes.

\section{Exploring informal education in Ghana}

Although Ghana has experienced high levels of economic growth in recent years, this has not translated into increased formal employment. The vast majority of jobs are found in the informal sector, which is characterized by insecure employment, irregular and low wages, and poor working conditions (Langevang 2008; Langevang et al. 2015). Like elsewhere in sub-Saharan Africa, for the predominantly youthful population the chances of obtaining formal employment are slim regardless of the level of education completed (Gough and Langevang 2016). Despite this prevailing situation, formal education is still prized very highly by Ghanaians. Spurred on by the Millennium Development Goal (MDG) for universal access to primary education, primary school attendance in most African countries has increased dramatically in recent decades (Rolleston 2011), and in Ghana is now over 90 percent. Although the six years of primary school and three years of Junior High School (JHS) have been free of charge for several decades, the final three years of Senior High School (SHS) were fee paying until 2017. Not only has SHS until recently been expensive but gaining entry is highly competitive due to limited spaces, resulting in only around 40 percent of students who complete JHS continuing to SHS (Aryeetey, Doh and Andoh 2013). The many young people who are unable to proceed to, or complete, SHS are derogatively referred to as "school dropouts" and often suffer discrimination and a lack of self-confidence. Consequently, despite there being few formal jobs for young people with school leaving certificates, obtaining one is still an aspiration for the majority of youth (Langevang 2008; Jones and Chant 2009; Porter et al. 2011).

A popular option for young people unable to continue in the formal education system is to turn to post-basic vocational education in the form of the apprenticeship system, which while prevalent throughout Africa is especially widespread and has a long history in western Africa, including Ghana (Lloyd 1953; Peil 1970; Fluitman 1992; Obidi 1995; Frazer 2006; Ahadzie 2009). Apprenticeships in Ghana originated as a way to reproduce skills within families and communities, hence were restricted to young people who belonged to a particular family/community and there were no contracts, payments or certification (Peil 1970; Palmer 2009). A similar observation has also been made for apprenticeships in other West African countries such as Cameroon (Wallaert-Petre 2001; Argenti 2002) and Nigeria (Lloyd 1953; Obidi 1995). This has changed, however, and today apprenticeships are widely claimed to be responsible for 80-90 percent of skills training in Ghana (Palmer 2007; Donkor 2012; Aryeetey, Doh and Andoh 2013). Whilst the learning process has continued to be primarily practical and work-based, with the instruction being conducted by so-called "masters" and "madams" (collectively known as "master craftspersons"), their apprentices may come from far and wide. The master craftspersons do not operate with a formal curriculum and the system is primarily self-regulated, with limited support or control by the government. The roots of this informal education are thus traditional but its current manifestations are contemporary (Hanson 2005).

Many trades in Ghana are highly gendered, and "gender stereotypes are still very strong in skills choices made by trainees" (Aryeetey, Doh and Andoh 2013, 148). As Schraven et al. (2013) found in their survey of apprenticeships in Ghana, female apprentices are primarily 
concentrated in two occupations - seamstress and hairdresser - whereas male apprentices are found in a wide range of occupations. For the purposes of this study, four trades - two predominantly female and two predominantly male, were selected: the female trades were the most common ones (seamstress and hairdresser), whilst for the male trades a more "traditional" (cane weaving) and a more "modern" (auto-repairs) trade were selected. The size of businesses found within each of these trades varies slightly, with many being operated soley by the owner while others have one or two informal employees, and potentially one or more apprentices. It is not so much the type of trade that determines the profitability of a business but rather the skills, access to finance and contacts of the owner, i.e. there is as much variability within trades as between trades.

The research took place in Accra, which as the capital city and major economic hub is the center of political and economic decision making in the country (Grant and Yankson 2003). The city has also long been a key site for apprenticeship training (Peil 1970). Key locations for each trade were selected within Accra for the fieldwork. For the auto-repairers, this was Odawna light industrial area located at the western edge of the Central Business District of Accra, where vehicle repair activities have been taking place since the early 1960s on a vast area of land allocated for the purpose by the government (Yankson and Owusu 2015). In the case of the cane weavers, three roadsides within Accra were studied: Motorway Extension, Spintex Road and Cantonments. In addition, some fieldwork also took place in the village of Enyiresi in the Eastern Region, about $70 \mathrm{~km}$ north of Accra, as many of the apprentices had returned to their hometowns due to it being the low season for cane weaving. As the work locations of hairdressers and seamstresses are not clustered but rather are spread throughout Accra, primarily in low-income residential areas, several such areas were studied.

In order to generate knowledge of the people involved in the apprenticeship system in Ghana and explore how apprenticeships are "performed, rehearsed and experienced in practice" (Mills and Kraftl 2014, 11), twenty apprentices and young workers were interviewed for each trade (eighty in total), along with several master-craftspersons (sixteen in total). During these interviews, the changing materialities and technologies of the various trades were examined and how these "enable and negotiate experiences of informal education" (Mills and Kraftl $2014,12)$. In order to investigate the regulation of the learning environment and the fluidity of the informal/formal education boundary, interviews were also held with all four respective trade associations and with a number of government agencies, including the National Vocational Training Institute (NVTI) and the Council for Technical and Vocational Education and Training (COTVET). All of these semi-structured interviews, which lasted between forty-five and ninety minutes, were conducted by the authors either in English or in a local language, depending on the preference of the interviewees. Some of the interviews were recorded and subsequently transcribed, whilst detailed notes were taken during the other interviews, either because the environment was not conducive to recording or the respondent was unwilling to be recorded. It is this data which forms the empirical core of this paper.

\section{Evolving apprenticeship system}

The nature of the apprenticeship system and how it is evolving in Ghana are explored in this section focusing first on the people and process of learning, second on the materialities, technologies and spatialities of the learning process, and third on the regulation of the learning environment.

People and everyday praxes 
Across the trades, at the start of an apprenticeship an oral contract is established and fees are paid by the apprentices' sponsor to the master craftsperson, both in money and in kind, and again at graduation. The fees charged vary according to the relationship of the master craftsperson with the apprentice's parents, their ability to pay, and the fees charged by others (Bryer 2007). Cane weaving still mainly attracts young people from villages in the Eastern and Western Regions where the cane weaving skill developed, even though the actual production has moved away from these communities of origin to Accra. The other occupations do not have the same kind of attachment to a particular place from where apprentices are drawn. Social networks, however, remain key in establishing apprenticeship contracts for all the trades. Often the parents or guardians of a potential apprentice will approach a master craftsperson, whom they either know or have had recommended to them by family or friends. This highlights the importance of intergenerationality (Vanderbeck 2007) and in particular the significance of the authority structure within families (Holloway et al. 2010), in the process of a young person embarking on a particular apprenticeship. As Frazer (2006) claims, drawing up a contract with an apprentice's parents or other sponsor is perceived to increase the commitment of the apprentice to completing, as to abscond would damage the reputation of the entire family; it also reflects the power structure within families.

Young people's motivations for entering an apprenticeship differ somewhat between the different trades. Regarding the cane weavers, the lack of modernization of the production process, work location along roadsides, and traditional products has resulted in the business being seen by many young people as only for school "dropouts" from rural areas. Although a few young people learn the skills as they grow up, most do not; rather on leaving school and looking for work they are advised by their parents/guardians that cane weaving is a good craft for them to learn. As the masters come from the same villages as most of the apprentices, connections are easily made for the young men to start an apprenticeship and make the move to Accra. As an apprentice explained:

The reason why we came into this business is that our brothers are in Accra so if you complete JHS and your mother doesn't have money to help you further your education they will come and pick you to stay with them in Accra and we learn it from them.

Dressmaking, like cane weaving, also tends to be seen as a trade for school dropouts because of the limited literacy requirement and lack of modernization of the profession, hence carries little prestige. Moreover, it is a relatively cheap profession to enter, only requiring the purchase of a sewing machine, making it attractive to those with fewer resources (Aryeetey, Doh and Andoh 2013). While some young dressmakers decide to pursue a dressmaking apprenticeship because of an interest in clothing and fashion (Langevang 2017), a much more common explanation is that they were pushed into the profession by their family as they were unable to further their education beyond JHS. As one dressmaker noted:

I wanted to be a nurse but because of financial problems I didn't get that opportunity, so my parents asked me to learn this seamstress work. At first I didn't like it, but I don't have any choice. I have to do it.

In contrast, while many hairdresser apprentices claimed to have had other career plans, which often included furthering their formal education, they were generally attracted to the hairdressing profession because of its modern image and association with literacy and looking smart (Langevang and Gough 2012). A young hairdresser explained how while at school her ambition had been to become a journalist, bilingual secretary or even a newsreader 
so she could be on the television. When that proved unrealistic she switched to hairdressing, which she saw as a profession that would also enable her to gain respect:

I found out that hairdressing is also good work ... I have to come out as somebody. I was thinking, when you are a journalist you have to be looking smart. OK, I can see that hairdressers also look very smart. So, I decided to start that.

Some young hairdressers emphasize their professional identity and superior skills, stressing that the profession is not for the uneducated (Langevang and Gough 2012). Similarly, young men entering the auto-repair business no longer regard it as a trade for uneducated youth due to the increasing proliferation of electronic vehicles and the need to have some basic ICT knowledge before entering the profession.

These changes highlight the complexity of the skills the apprentices have to learn, combined with the formalization of part of the training and official certificates awarded (Yankson and Owusu 2015). This shows how the four trades have different relationships to geographically bounded communities of practice, which together with the materialities, technologies and spatialities of the learning process, and the regulatory apparatus, impact who enters the professions and how. It also paints a very different picture to the one put forward by Mills and $\operatorname{Kraftl}(2014,3)$ who suggest that young people "should willingly engage in informal educational programmes and themselves identify the issues that should be addressed". Although some young people willingly enter apprenticeships, others are pressured into this form of informal education, often only complying as they are aware that it can enable them to obtain vital skills for future livelihoods.

Apprentices typically work/learn for ten hours a day, six days a week for a period of around three years. The length of time it takes to complete an apprenticeship varies depending on the competences of the apprentice and "How fast his [sic] brain is" (Jaarsma et al. 2011, 444). Master craftspersons can have from one to as many as twenty apprentices, though typically have two to five at differing stages of learning the craft. Hairdressing is the trade where the greatest number of apprentices are found, who are often visible due to their matching uniforms. Apprentices are unpaid but may receive a daily allowance (referred to as "chop money") to buy food with. This is rarely enough for the apprentices to live off, hence they have to find ways of supplementing this money (see also Hanson 2005). Many apprentices interviewed reported being still dependent on their parents, again highlighting the importance of intergenerational relations. A grey area is what happens in the case of illness or an accident incurred on the job. As one auto-repair apprentice claimed:

When the apprentices get wounded [on the job] sometimes their masters don't take good care of them. They just sack them to go back to their homes to get healed before they come back again to work.

Whilst some master craftspeople are very supportive of their apprentices, taking good care of them personally and professionally, others take advantage of being in a position of power and exploit their apprentices using them as free labor.

Common to the learning process for all four trades is the apprentices having to do a range of menial jobs, including fetching water, running errands and, in the case of young women, looking after their madam's children at the start of their apprenticeship. None of these activities have anything to do with acquiring skills but are tasks that the apprentices are obliged to perform. Gradually they become increasingly involved in the trade through an education system of "learning through observation", which involves looking, learning, 
practising and perfecting skills over time. As well as obtaining technical skills, social learning is also a central aspect of apprenticeship training. The apprentices learn good customer service and other business related skills, and indirectly build up social relations which they can potentially take with them if they subsequently set up their own business. Whilst becoming a business owner is the aspiration of the vast majority of apprentices, not all have the resources or acumen to do so, resulting in them becoming informally employed with low wages and insecure conditions (Gough, Chigunta and Langevang 2016).

Each trade has a particular order in which skills are learnt. For auto-repairers, a new apprentice will typically assist his co-workers in their work, including fetching tools, collecting parts, running errands and cleaning the workshop. Gradually the apprentice will be trusted with doing the simpler tasks on his own, such as changing tyres or adjusting brakes. Over time his competences will increase - "the closer to the engine, the closer to mastery" (Jaarsma et al. 2011, 443). When a range of advanced jobs have been mastered, the apprentice will start teaching other apprentices before graduating, at which point he has gained the competency to set up his own workshop. Similarly, a dressmaker apprentice will typically spend the first months observing, running errands, ironing and attaching buttons, before being trusted with first sewing and later cutting garments. In this way, the learning process is reversed as the apprentice starts by learning the finishing steps of producing a garment before the first steps, cutting being the most critical aspect to get right. Hairdresser apprentices, by contrast, learn the skills first by watching their madams and then by practising on each other before subsequently doing the hair of customers. Cane weavers tend to master one task at a time, such as weaving or framing, before learning another skill but there is no specific order in which they learn the skills and several specialists are often involved in producing a set of furniture. In all of the trades, a hierarchy and associated power relations develop among the apprentices under a specific master craftsperson related to the length of their training and their competences.

The mode of learning underpinning this form of informal education is well captured by Lave and Wenger's (1991) concept of "legitimate peripheral participation" within "communities of practice". Their theory of learning has been influential in explaining how "old timers" pass on their skills to "novices" as a means for the community to reproduce itself (Fuller and Unwin 2011; Jaarsma et al. 2011), highlighting the intergenerational transfer of skills. Accordingly, learning involves a process of gradually moving from the periphery of a setting to becoming a fully accepted member of a professional community, and in the process moving into a more powerful position. Learning is not achieved through the transmission of abstract and decontextualized knowledge from the teacher to the student, but is seen as a social process involving the increased participation of the apprentice in the professional community (Lave and Wenger 1991).

It is important to acknowledge that informal education is not necessarily "free of societal ordering and control" but can be "governed by social norms and structured by gender and generational relations" (Smith and Phillips 2017, 70). Moreover, apprenticeships serve not only as the transfer of knowledge and skills but also as a gatekeeping structure and form of power relations by which knowledge can be transmitted or retained (Argenti 2002).

According to Argenti $(2002,499)$, "the apprenticeship relation represents first and foremost a negotiation of relations of power". The prevalent view that "the master is infallible" results in a situation whereby "the apprentice is obliged in all cases of dispute to submit to the authority of the master" (Ahadzie 2009, 286). Complaints heard from both masters/madams and apprentices, however, reflect the contestation of the master-apprentice relationship, and the possible renogotiation and changing boundaries of these relationships. 
One trend that emerges from all four trades, to the frustration of many master craftspersons, is the move by apprentices away from completing full apprenticeships of around three years in duration to only partially completing. In some cases, this occurs because the young people lack money to finish the entire training, and in other instances because the apprentice decides to specialize in just one aspect of the trade in order to earn money sooner than would otherwise be the case. As young people in Ghana are increasingly being exposed through television and other media to a "fast life" that they want to partake in (Langevang 2008; Esson 2013), this is contributing to changing their aspirations. Especially the male apprentices explained that "times have changed" and they do not have the time or money to go through a long apprenticeship; they feel the need to generate an income in order to live up to their responsibilities of taking care of themselves and their families. Some apprentices also complained about the control and regimental life that an apprenticeship typically implies, emphasizing that they do not want to "feel bound" but wish to become independent as quickly as possible. This differs from the situation twenty years ago when Obodi $(1995,369)$ found that "apprenticeship teaches devotion to duty and hard work and inculcates in the apprentice discipline and the desire to become an accomplished craftsman".

Many cane weavers specialize in just one aspect of the profession, such as framing, weaving or spraying. By training for a shorter period of time they can earn money sooner by working freelance for a master who needs a particular task to be done. Such income, however, is sporadic and they are not able to set up their own business and take on apprentices as they do not have all the required skills. This is not necessarily seen as a disadvantage by the young men who consider themselves as specialists. Similarly, for the auto-mechanics, most of the young apprentices do not acquire the full range of skills necessary to become master craftsmen. The high cost of completing an apprenticeship, combined with their need to earn money, results in many apprentices only learning part of the auto-repair trade. As one master explained:

The youth of today ... if they learn just how to fix a plug and brake they want to leave. Some of them have had access to money before they came to learn the job and when they see their masters making money they also want quick money so they leave with the mind to establish themselves after one or two years. ... Some don't even want to learn the job but try to learn how to drive trotro [minibus] or taxi and then leave.

In a strategic move, some apprentices who have only partially completed their training team up with others in a similar situation to establish a joint workshop or move into activities such as driving commercial vehicles or the sale of auto spare parts. Becoming a driver is especially attractive to apprentices as they can use their mechanical skills if the vehicles they are driving break down.

Similarly, young women do not always complete the full apprenticeship. A young woman may just learn hair braiding then set up her own business specializing in this aspect alone. Not only is this a quick path to earning money but it avoids the expense of having to invest in dryers which, due to their high cost, previously hindered many qualified hairdressers from being able to establish their own business. Within dressmaking, apprentices also increasingly only learn one aspect of the trade, such as overlocking or knitting. Moreover, in recent years some seamstresses have been drawn into the booming second-hand clothing industry (Brooks 2015), playing a key role redesigning the imported clothing to suit the styles, sizes and/or climate of Ghana. For some aspiring seamstresses who are unable to complete their 
apprenticeship, such alteration work provides a way into self-employment. An alteration seamstress explained:

I did a seamstress apprenticeship for two years but I didn't finish. I couldn't complete because I got pregnant. That is how I landed myself into the alteration business...After delivering [giving birth] I came to sell second-hand clothes for four years at Makola market [central Accra]. Because of the hard work walking in the sun I decided to start doing this work. I had learnt how to sew so I had knowledge of the basics and I felt that alterations would help me more.

While some young people become alteration seamstresses by default, others start out with the intention of becoming one since the training at the vast second-hand market of Kantamanto in Accra only lasts a few months and is usually conducted between acquaintances with no contract made or fees charged. The trainee, however, only learns one skill, such as cutting or stitching, hence is limited to doing this one task.

Many of the master craftspeople lamented this situation where young people only learn one aspect of the trade, seeing it as a lack of commitment and complaining that "the young people are in a hurry" and are only interested in "fast money". It can be argued, however, that for young people learning one skill which they then practise is a more pragmatic way forward. As technologies and products become more sophisticated, as the next section shows, specialization is increasingly a rational decision for workers in the informal economy. Moreover, leaving an apprenticeship prior to completion enables those apprentices who are being exploited to escape and become independent. This in turn will have implications for the training of apprentices; as there will no longer be masters and madams who are skilled in all aspects of a trade, the training is likely to become shorter, more specialized and consequently cheaper. These changes could have a major impact on the entire apprenticeship system with apprentices no longer becoming "full participants" of large "communities of practices" (Lave and Wenger 1991) but instead participants of "sub-communities of practice".

\section{Materialities, technologies and spatialities of learning}

The nature of the materials and technologies being used in the respective trades, and changes in these over time, affect the skills the apprentices need to attain and the type of education required. In the case of the auto repair and hairdressing trades, the nature of the work being undertaken has changed dramatically in recent years linked to technological and product development at a global scale. Changes in vehicle manufacturing technology have resulted in the use of computers to detect and rectify faults, skills that are beyond those acquired through the traditional apprenticeship system. Some masters require their apprentices to have senior secondary school education before starting their training, and many apprentices take the formal examinations in order to have the possibility of also obtaining employment with largescale private and public sector institutions on completion. This indicates how skills obtained in what is perceived as an informal education system can result in formal sector employment, highlighting how informal education does not only lead to informal work.

The products used in hairdressing have also changed substantially in recent years. Through the mass media, Ghanaian women have become exposed to hairstyles that require new products (such as chemicals for straightening hair) and new techniques (such as hair relaxing and adding weave-ons), which have become increasingly available in Ghana due to trade liberalization (Oda 2005). These new styles and the associated products and processes result in few women being able to do their hair themselves, hence they visit hairdressers frequently 
(Langevang and Gough 2012). For hairdressers to be able to work with the new hair products they have to learn new skills that were not formerly part of the apprenticeship training. Consequently, many apprentice hairdressers take courses and exams offered by their trade associations. This shows how, in both the auto-repair and hairdressing trades, in order to enter the profession apprentices require a higher level of formal education than previously, in most cases at least JHS, and in the case of the auto-mechanics and even some hairdressers, increasingly SHS. It also illustrates how informal and formal education do not necessarily constitute separate educational pathways but are often intersected and can be combined.

This situation contrasts sharply with the cane weaving and dressmaking trades where the technologies used have changed very little. Following the failure of early attempts to mechanize the profession, cane weavers are still using traditional techniques. Preparing the bamboo, making the frame, weaving and then spraying the finished product are all done by hand. In the case of seamstresses, although electric sewing machines are increasingly replacing (or complementing) treadle sewing machines, and new materials and fashion styles are constantly coming onto the market, the skills required and hence training undertaken by seamstresses has changed little over the years. As both professions are still using traditional techniques that do not require high levels of education, they suffer from the image of being for school drop outs. The cane industry is facing an additional problem regarding the sourcing of raw materials. As there is no cultivation of cane in Ghana, it has to be collected wild which, as the weavers explained, is making it increasingly difficult for them to source cane. Problems accessing raw materials are not restricted to cane weavers in Ghana but are also reported for basket weavers in the north of the country who rely on straw (Olwig and Gough 2013), and for handicraft producers in other contexts (Gough and Rigg 2012; Harris 2016). For the cane weaving industry, this problem is compounded by facing acute competition from cheap imported Asian products, such as baskets, despite being made from poorer quality, cultivated cane. The limited availability of the raw materials for cane weaving, alongside falling demand for their products, are directly affecting the number of apprentices that master cane weavers can take on.

As well as the materialities and technologies of the learning process affecting the apprenticeship system, the spaces in which the learning process takes place also affects who enters the respective trades and the apprentices' learning experiences. The male dominated trades tend to be clustered together in specific locations, enabling those within the profession to benefit from being able to collaborate and support each other, as well as increasing competition and lowering prices. Due to space being at a premium, this results in cramped working and living environments as many of the apprentices also sleep at their workplaces, often in unsanitary conditions, blurring the distinction between home and workplace. The apprentices thus become participants in a geographically based community of practice where an important part of the learning process is being capable of navigating the environment (cf. Jaarsma et al. 2011).

The cane weavers lack not only a safe place to live but also a secure place to work. Master cane weavers have established themselves in a few key locations in the city, primarily alongside the busy roads their potential customers pass along, often at a slow speed due to the heavy traffic. Although the cane weavers' presence is generally tolerated by the authorities, despite being illegal, due to their weak bargaining position they suffer harassment by officials and have had to move several times in relation to road expansions in recent years. According to the masters, this insecurity results in them being unable to expand their businesses as they would like and restricts the number of apprentices they take on. In turn, the lack of a secure 
living and working environment deters some young people from entering the profession. One of the apprentices recounted some of the challenges they face, which also demonstrates the blurring of home and work, claiming, "We don't have a good place to sleep so when it is the rainy season it becomes such a problem for us. We don't have a place for our items so it also disrupts our work." The Cane Weavers Association has entered into discussions with the government regarding finding a secure working place but their weak negotiating position resulted in the land allocated being too far away from any customers. As one of the masters stated, "This work does not like obscure places. It depends on a visible place. If you put us in an obscure place, then you knock the life out of our work." Power struggles also take place between masters over access to land in prime locations, with the more established masters generally occupying the better spaces. These spaces of informal education are thus both informally and formally regulated.

In contrast, the female dominated trades, as exemplified by the cases of the hairdressers and seamstresses, tend to operate out of the home of the madam or in wooden shacks or metal containers located close by (Gough 2010). Since it is not considered appropriate for women to live "rough", as many of the male apprentices do, and there is rarely space for female apprentices to live with their madams, most female apprentices either live in their own home or stay with relatives/friends. Consequently, their home and work spaces are usually separate and their living arrangements are less physically challenging than the spaces occupied by many male apprentices, though may still be cramped. Contrary to the image projected by studies of informal education in a global North context, which tend to take place "in locales where young people themselves choose to be and are most comfortable - be they youth clubs, street corners, bus stops or religious institutions" (Mills and Kraftl 2014, 3), spaces of informal education can also be very challenging spaces for young people, especially young men.

\section{Regulatory apparatus}

While the apprenticeship system in Ghana is informal, in the sense that it has been subjected to limited state regulation and is largely self-regulated by the master craftspersons with no formal contracts entered into, there have been various attempts by the government to upgrade, formalize and modernize the system. Since it was established in 1970, the National Vocational Training Institute (NVTI) has had a Department of Apprenticeships with the mandate of regulating and controlling all forms of apprenticeship training. Their focus, however, has predominantly been the provision of formal apprenticeship training at NVTI centers, with little engagement with the informal apprenticeship system (Palmer 2009). Consequently, in 2006 the Council for Technical and Vocational Education and Training (COTVET) was set up by the government, supported by various international development partners, to coordinate and oversee all aspects of technical and vocational education and formulate national policies for skills development across formal and informal sectors. An official from COTVET stressed that they have an informal sector affairs division "tasked with developing policies and programmes for strengthening informal apprenticeship training".

In line with apprenticeships being seen as providing an option for young people who would otherwise be unemployed (Frazer 2006), an ambitious plan for a National Apprenticeship Programme (NAP) was launched in 2011. The NAP, however, has had minimal impact due to its focus on placing a limited number of JHS graduates in an apprenticeship, many of whom reportedly have government contacts. Moreover, despite legislative regulations of informal 
apprenticeships being included in a number of Acts (for example, NVTI Act of 1970, Apprenticeship Training Regulations of 1978 and Children's Act of 1998), which state amongst other things the minimum age of apprentices, masters/madams' responsibilities towards apprentices, and the agreement, duties and release of apprentices, these regulations have proved largely ineffective (Palmer 2009), with few masters and apprentices we spoke to even being aware of their existence.

Alongside state intervention, in recent years informal sector associations have mushroomed in Ghana and elsewhere in sub-Saharan Africa (Lindell 2010). It has been argued that these associations form the strongest element of the apprenticeship institutional framework, playing a key role in the regulation and supervision of skills training (Haan and Serriére 2002; Palmer 2009). The nature of the role they play, however, varies according to the trade.

Among the more successful are the two main associations for hairdressers: the Ghana Hairdressers and Beauticians Association (GHABA) and the National Association of Beauticians and Hairdressers (NABH). Both associations have become involved in the standardization and monitoring of their respective professions through introducing classbased training of apprentices following a pre-set syllabus. The associations have also been involved in the development of the NVTI examination and certification of hairdressers, which all members are encouraged to take. "We want to bring the apprentices to a standard ...we wanted a certificate which has weight and mixes the practical and theoretical aspects of hairdressing so we have worked with NVTI", an executive of GHABA explained. As part of this examination, the apprentice has to partake in practical tasks - such as setting up a salon, receiving customers and treating their hair - as well as taking oral or written exams on theoretical aspects of hairdressing (Langevang and Gough 2012).

In addition, the hairdresser associations frequently hold training sessions and workshops to educate the madams in new techniques/products and to discuss their role as educators. Meetings are also held exclusively for the apprentices at the local level where they can exchange experiences and try to resolve their daily challenges. To promote their activities, the associations have created links to local private hair product manufacturers and transnational hairdresser networks. The professionalization of the training and modernization of the techniques have resulted in a formalizing of part of the apprenticeship system and the profession being seen as more modern and desirable by potential hairdressers than previously (Oda 2005). Consequently, whilst hairdressing has long been a trade young women have entered, there has been a boom in the number of hairdressers since the late 1990s (Langevang and Gough 2012). As an executive of NABH explained, "Hairdressing is a good profession. The beauty industry is thriving ... the future is bright". Hairdressers who are members of one of the associations, and have taken their NVTI exams, often sell their services based on their education and ability to talk about their work in a professional way. Hence, through the affilation to the association, hairdressers are able to distinguish themselves as the most qualified. A 23 year old hairdressing salon owner explained how,

So many people they love to come here ... Because of the NVTI and the grade that I have, I have been telling them ... my business here is different because I am having a professional work here.

The Ghana National Association of Garages (GNAG) comprises of auto-mechanics, autoelectrical technicians, auto-welders and motorbike mechanics. The Odawna branch of GNAG represents the auto-repairers located there. The branch has been responsible for allocating plots of land to individuals to establish their workshops, although nowadays there is a long 
waiting list for plots and no more land to allocate. This resulted in some masters complaining that the only benefit of being a member of an association is that they help with funeral costs. The Odawna branch, however, has negotiated a tax rebate with the internal revenue agency for its members, and when a new product is introduced the manufacturers invite the autorepairers to seminars held at major hotels in Accra to enable them to learn the requisite skills. Members also reported that it was easier for them to obtain a loan if the chairman of the local association would act as a guarantor, which can be important for apprentices trying to set up in business.

The Ghana National Tailors and Dressmakers Association (GNTDA) is one of the largest informal sector associations in Ghana, though it is currently experiencing falling membership. Similar to the hairdressers and auto-mechanics, GNTDA has attempted to regulate the apprenticeship system by introducing a common apprenticeship registration form and a syllabus which includes some theoretical aspects and a common exam. The primary focus of their teaching is on the reproduction of practical skills, hence the trade can be undertaken by young women with little schooling. Concerns have been raised among some dressmakers that there is a need to introduce more "modern" ways of making clothes, such as teaching fashion design and training in the use of patterns. One executive of the association lamented that lack of monitoring and regulating of skills training had implied that "Dressmaking has become like a third-class job" and that many apprentices "learn to sew anyhow because the madams are not well trained". Yet, elements of the leadership of the association believe that the old apprenticeship system, with its focus on practical skills and free-hand cutting, is adequate and does not need changing (Langevang and Gough 2012). Executives of the association lament that the government has done little to reduce imports of cheap garments from Asia and second-hand clothing, primarily from Europe and the USA, which they perceive to have ruined the industry by making it cheaper for Ghanaians to buy these rather than have garments made by a seamstress or tailor. Following lobbying by the GNTDA, however, the government introduced a "Friday wear campaign" that encourages all public sector workers to wear "traditional" custom-made clothing on Fridays to try to counter the falling demand for such clothing. This strategy has been highly successful and increasingly, in both the public and private sector, uniforms are also being commissioned from seamstresses and tailors, helping to boost life into an otherwise flagging trade.

At each of the cane weaving sites in Accra, there is a local association with elected leaders. As the cane weavers have recognized the benefits of presenting a united front to the government, in particular in their efforts to obtain a secure and permanent working site, in 2012 an umbrella body - Countrymen Cane Weavers Association (CCWA) - was formed, which the local associations are affiliated to. Despite several promises from the government to resettle the cane weavers, this has not occurred and the CCWA is seen as being relatively weak by most cane weavers. Since CCWA sees its main task being to secure a permanent location for their members to engage in their trade, it has not sought to deal with other issues, such as regulating or upgrading the apprenticeship system. Consequently, the training process has changed little and the association does not monitor the training process nor examine apprentices.

This discussion of the activities of the respective trade associations shows how their roles and achievements vary. Some associations, typified by the cane weavers and dressmakers' associations, either do not have the capacity to serve the interests of their members adequately or do not see the need to change the current apprenticeship system. The relative lack of leadership, combined with limited change in the techniques and tools used, has resulted in the education for these trades hardly changing. This is most extreme in the case of 
the cane weavers who, out of the four trades studied, are the only one unable to obtain a formal certificate. Other trade associations - as illustrated by the hairdressers and autorepairers - have established themselves as important actors playing an active role in supervising apprenticeship training and facilitating skills upgrading.

In order to ensure the quality of the training, and build up a good reputation for their trade, these associations have increasingly played a key role in formalizing their profession by regulating the entry requirements, checking standards, producing certification, and/or encouraging the apprentices to pursue a formal NVTI qualification. Obtaining a formal certificate is increasingly important for apprentices who, due to greater mobility, are likely to look for work outside of the local area where they have trained, potentially even within the formal economy; the testimonials provided by an apprentice's master or madam are typically not recognized beyond the immediate community. While the key aim of the associations' efforts is to raise the quality of the training, and thereby the standard and value of the work done, the increased emphasis on formal education makes apprenticeships increasingly difficult for young people without any formal education to enter. By becoming more exclusive, the associations are in effect regulating young people's access to the world of work.

This analysis of the regulatory apparatus shows how informal education is not necessarily beyond the control of formal institutions. Whilst the impact of state policies directly aimed at regulating the apprenticeship system has been minimal, actions of the state, in particular following the lobbying of trade associations, can influence specific trades (either positively or negatively), which in turn affects the number of apprentices master craftspersons can take on. The apprenticeship education system itself has been influenced more by the activities of the trade associations, which to varying degrees have introduced more formal modes of teaching and examining. It is important, however, not to overstate the governing role of these associations. Only a fraction of those operating within the trades have joined their respective associations, thus they are not directly subject to their regulations (though may still be indirectly influenced). As has been found for informal trade associations across Africa, their possibilities for instigating real change are relatively limited (Lindell, 2010).

The analysis in this section has illustrated how informal education systems are regulated by governments and other actors to varying degrees, have differing links to formal educational institutions and may over time become partially formalized, blurring the formal/informal education divide. The degree of regulation that apprenticeships are exposed to has important implications for young people's motivations for and ability to enter a trade, their everyday praxes and the materialities of their learning spaces. The formalization of the training systems, together with the introduction of new products and technologies and the corresponding skills needed to master these, have resulted in the professional image of some trades improving (such as hairdressing and auto-mechanics) making them more attractive to prospective apprentices.

\section{Conclusions}

This paper has explored the characteristics and changing nature of apprenticeships in Ghana, illustrating how they are an important form of informal education in a global South context. In this concluding section, we turn to consider how these Southern experiences provide a different picture of informal education compared with in the global North (Mills and Kraftl 
2014), forcing a rethinking and revisioning of how we conceptualise education. Three key factors are highlighted: the core elements of an analytical framework developed to study informal education; the ambiguous and changing distinction between informal and formal education; and the need to expand the agenda of informal education within geography.

First, the analytical framework developed in this paper has demonstrated how studies of informal education should include an analysis of regulatory institutions, which needs to be linked to the people, everyday praxes and power struggles they engage in, and the materialities, technologies and spatialities of learning. All of these factors are constantly being disrupted and remolded, though the extent and character of these changes differ between trades, related in part to the varying impact of processes operating from the global to the local level. As a result of processes of globalization, economic restructuring and local socio-economic change, young people are increasingly facing a constrained labor market and are concerned about the costs, time perspective, income-generating possibilities, as well as the professional image of the trade they choose to enter. Valuing formal education and certification highly, which some of the trade associations have played a key role in introducing, young people consider trades that are unable to combine on-the-job training with more formal forms of education and produce certification upon graduation as inferior. This, combined with the changing material conditions of the trades, has resulted in the aspirations and learning practices of the apprentices also evolving. Moreover, in order to shorten their time spent training and hence decrease the cost, and in some instances to escape the control of their masters/madams, many young people decide not to complete their apprenticeships and specialize instead in one part of a trade - a trend that is reforming the apprenticeship system radically. This shows the importance of considering power relations in spaces of informal education and how young people are not only shaped by but can also shape informal education (Mills and Kraftl 2014).

Second, this analysis of the apprenticeship system in Ghana has implications for how we conceptualise informal education and the distinction between informal and formal education. Some aspects of the learning system remain informal, some are being formalized, whilst others are informalised, though the extent and nature of these changes vary considerably by trade. Although the apprenticeship system is classified as informal education, it does not always fall outside of formal regulatory mechanisms, illustrating how the boundary between informal and formal education is by no means clear-cut (Fuller and Unwin 2011). Consequently, as this study of informal education from a global South context has demonstrated, scholars researching geographies of education need to rethink the informal/formal education divide and consider how processes of informalisation and formalization can occur concomitantly.

Third, this paper has highlighted the need to expand geographies of informal education to include apprenticeships, which are central to many young people's attempts to generate livelihoods in the global South. Rather like Rigg (2007) argued a decade ago for the agenda of the mobility turn to be expanded to consider livelihoods, studies of informal education by geographers need to move beyond their current global North focus on cultural aspects to incorporate issues that have emerged as being relevant in a global South context. This call to include livelihood-related issues in informal education scholarship should resonate beyond the global South to include studies of apprentices conducted in the global North. As Patchett $(2017,31)$ recently argued, apprenticeships ought to become "a central geographical concern". This applies not only to geographies of education but also to geographers who study labor and business dynamics, since apprenticeships affect access to labor markets and opportunities to establish a business. 
Whilst the key aim of this paper is to shape geographies of informal education from Southern experiences (cf. Cornell 2007), it is important that readers are not left with the impression that informal education in the global South is only about livelihoods. As in a global North context (Mills and Kraftl 2014), informal education in the global South also involves learning about values, social character and citizenship. Due to the relatively limited focus on these aspects of informal education in a global South context by geographers to date, such areas also warrant further research.

\section{Acknowledgements}

The Consultative Research Committee for Development Research (FFU) under Danida (project No. 09-059KU) funded the research that this paper builds on. The paper has benefitted greatly from informal presentations to, and conversations with, numerous colleagues. Special thanks to Peter Kraftl, Sarah Mills, James Esson and members of the Centre for Business and Development Studies at Copenhagen Business School, as well as the anonymous reviewers for their constructive comments on earlier drafts. The support of the Editor Nik Heynen was also much appreciated.

\section{References}

Ahadzie, W. 2009 The traditional informal apprenticeship system of West Africa as preparation for work, in Maclean, R. and Wilson, D. (eds) International handbook of education for the changing world of work, Springer, 261-275

Argenti, N. 2002 People of the chisel: Apprenticeship, youth, and elites in Oku (Cameroon), American Ethnologist, 29(3): 497-533

Aryeetey, E., Doh, D. and Andoh, P. 2013 Choosing an apprenticeship: skills preferences amongst the youth, International Development Planning Review, 35(2): 135-153

Aufseeser, D. 2014 Limiting spaces of informal learning among street children in Peru. In: Mills, S. and Kraftl, P. (eds.) Informal education, childhood and youth: Geographies, histories, practices, 112-123. Basingstoke: Palgrave Macmillan.

Bannister, C. 2014 'Like a Scout Does... Like a Guide Does...': The Scout or Guide Camp's Lessons of Identity. In: Mills, S and Kraftl, P.(eds.) Informal Education, Childhood and Youth: Geographies, histories, practices, 36-47. Basingstoke: Palgrave Macmillan.

Breyer, J. 2007 Financial arrangements in informal apprenticeships: determinants and effects. Findings from Ghana. Working paper no. 49. International Labour Office, Geneva

Brooks, A. 2015 Clothing poverty: the hidden world of fast fashion and second-hand clothes, London: Zed Books

Busso, M., Cristia, J., Hincapié, D. Messina, J. and Ripani, L. 2017. Learning Better. Public Policy for Skills Development. Inter-American Development Bank (IDB)

Cartwright, I. 2012. Informal education in compulsory schooling in the UK: Humanizing moments, utopian spaces. In: Kraft, P., Horton, J. and Tucker, F. (eds.) Critical Geographies of Childhood and Youth: Contemporary policy and practice, 151-166. Policy Press. 
Collins, D. and Coleman, T. 2008 Social geographies of education: looking within, and beyond, school boundaries, Geography Compass (2):281-99.

Cornell, R. 2007 Southern theory: the global dynamics of knowledge in social science, Allen and Unwin.

Dickens, L., \& Lonie, D. 2014. Rehearsal Spaces as Children's Spaces? Considering the Place of Non-formal Music Education. In: Mills, S and Kraftl, P.(eds.) Informal Education, Childhood and Youth: Geographies, histories, practices, 165-183. Basingstoke: Palgrave Macmillan.

Donkor, F. 2012 Reasons for non-completion among apprentices: the case of automotive trades of the informal sector in Ghana, Journal of Vocational Education and Training, 64(1): $25-40$

Esson, J. 2013 A body and a dream at a vital conjuncture: Ghanaian youth, uncertainty and the allure of football. Geoforum, 47, 84-92.

Esson, J., Noxolo, P., Baxter, R., Daley, P. and Byron, M. 2017 The 2017 RGS-IBG chair's theme: decolonizing geographical knowledges or reproducing coloniality? Area, 49(3): 384388

Fluitman, F. 1992 Traditional apprenticeship in West Africa: Recent evidence and policy options. Discussion Paper, 34. International Labour Office, Geneva (Switzerland).

Frazer, G. 2006 Learning the master's trade: Apprenticeship and human capital in Ghana, Journal of Development Economics (81): 259-298

Fuller, A. and Unwin, L. 1998 Reconceptualising apprenticeship: exploring the relationship between work and learning, Journal of Vocational Education and Training 50 (2): 153-173.

Fuller, A., \& Unwin, L. 2009 Change and continuity in apprenticeship: The resilience of a model of learning. Journal of Education and Work, 22(5), 405-416.

Fuller, A. and Unwin, L. 2011 Apprenticeship as an evolving model of learning, Journal of Vocational Education and Training, 63(3): 261-266.

Gospel, H., \& Fuller, A. 1998. The modern apprenticeship: new wine in old bottles?. Human Resource Management Journal, 8(1). 5-22.

Gough, K.V. 2010 Continuity and adaptability of home-based enterprises: a longitudinal study from Accra, Ghana, International Development Planning Review, 32(1): 45-70.

Gough, K.V., Chigunta, F. and Langevang, T. 2016 Expanding the scales and domains of insecurity: youth employment in urban Zambia, Environment and Planning A, 48(2): 348-366

Gough. K.V. and Langevang, T. 2016 Introduction: Youth entrepreneurship in sub-Saharan Africa, in Gough, K.V. and Langevang, T. (eds) Young entrepreneurs in sub-Saharan Africa, London and New York, Routledge

Gough, K.V., and Rigg, J. 2012. Reterritorialising rural handicrafts in Thailand and Vietnam: a view from the margins of the miracle. Environment and Planning A, 44(1): 169-186. 
Grant, R. and Yankson, P. 2003 Accra, Cities, 20(1): 65-74

Haan, H., and Serrière, N. 2002. Training for work in the informal sector: Fresh evidence from western and central Africa. Turin, Italy: ITC/ILO.

Hanson, K. 2005 Vulnerability, partnerships and the pursuit of survival: urban livelihoods and apprenticeship contracts in a West African City, GeoJournal, 62: 163-179

Hanson Thiem, C. 2009 Thinking through education: the geographies of contemporary educational restructuring, Progress in Human Geography, 33, pp. 154-73.

Harris, J. 2016. Joint action in Nairobi's informal handicraft production clusters. International Development Planning Review, 38(3): 317-337.

Holloway, S., Hubbard, P., Jöns, H. and Pimlott-Wilson, H. 2010 Geographies of education and the significance of children, youth and families, Progress in Human Geography, 34(5): $583-600$

Holloway, S. and Jöns, H. 2012 Geographies of education and learning, Transactions of the Institute of British Geographers, 37: 482-488

Jaarsma, T., Maat, H., Richards, P. and Wals, A. 2011 The role of materiality in apprenticeships: the case of the Suame Magazine, Kumasi, Ghana, Journal of Vocational Education and Training, 63(3): 439-449

Jones, G.A. and Chant, S. 2009 Globalising initiatives for gender equality and poverty reduction: exploring 'failure' with reference to education and work among youth in The Gambia and Ghana, Geoforum 40: 184-196

Kraftl, P.P. 2013a Geographies of Alternative Education: Diverse Learning Spaces for Children and Young People. Bristol: Policy Press.

Kraftl, P P. 2013b 'Towards Geographies of Alternative Education: A Case Study of UK Homeschooling Families', Transactions of the Institute of British Geographers 38: 436-450.

Kraftl, P.P. 2014 Alter-childhoods: biopolitics and childhoods in alternative education spaces, Annals of the Association of American Geographers, 105(1): 219-237

Kyle, R. G. 2014 Inside-out: Connecting indoor and outdoor spaces of informal education through the extraordinary geographies of The Boys' Brigade camp In: Mills, S. and Kraftl, P.(eds.) Informal Education, Childhood and Youth: Geographies, histories, practices, 21-35 Basingstoke: Palgrave Macmillan.

Langevang, T. 2008. 'We are managing!'Uncertain paths to respectable adulthoods in Accra, Ghana. Geoforum, 39(6): 2039-2047.

Langevang, T. 2017 Fashioning the future: entrepreneuring in Africa's emerging fashion industry, European Journal of Development Research, 29(4): 893-910

Langevang, T. and Gough, K.V. 2012 Diverging pathways: young female employment and entrepreneurship in sub-Saharan Africa, The Geographical Journal, 178(3): 242-252 
Langevang, T., Gough, K.V., Yankson, P., Owusu, G. and Osei, G. 2015 Bounded entrepreneurial vitality: the mixed embeddedness of female entrepreneurship, Economic Geography, 9(4): 449-473

Lave, J and Wenger, E. 1991 Situated learning: legitimate peripheral participation. Cambridge University Press.

Lemanski, C. 2014 Hybrid gentrification in South Africa: Theorising across southern and northern cities. Urban Studies, 51: 2943-2960.

Lindell, I. 2010 Introduction: the changing politics of informality - collective organizing, alliances and scales of engagement, in: Lindell, I. (ed.): Africa's informal workers: collective agency, alliances and transnational organizing in urban Africa. Nordiska

Afrikainstitutet/Zed Books: London, 1-30.

Lloyd, P. 1953 Craft organization in Yoruba towns. Africa: Journal of the International African Institute, 23: 30-44

McCreary, T., Basu, R. and Godlewska, A. 2013 Critical Geographies of Education: Introduction to the Special Issue. The Canadian Geographer / Le Géographe canadien, 57: 255-259

Meagher, K. 1995 Crisis, informalization and the urban informal sector in sub-Saharan Africa, Development and Change, 26(2): 259-284

Mills, S. 2015 Geographies of youth work, volunteering and employment: the Jewish Lads' Brigade and Club in post-war Manchester. Transactions of the Institute of British Geographers, 40(4), 523-535.

Mills, S. 2016 Geographies of education, volunteering and the lifecourse: the Woodcraft Folk in Britain (1925-75). Cultural Geographies, 23(1), 103-119.

Mills, S. and Kraftl, P. 2014 Introduction: Geographies, histories and practices of informal eduction, in Mills, S. and Kraftl, P. (eds.) Informal education, childhood anf youth: geographies, histories, practices, Basingstoke: Palgrave Macmillan

Mills, S. and Kraftl, P. 2016 Cultural geographies of education, Cultural Geographies, 23(1): $19-27$

Obidi, S. S. 1995 Skill acquisition through indigenous apprenticeship: A case study of the Yoruba blacksmith in Nigeria, Comparative Education, 31(3): 369-383

Oda, Y. 2005 Women working at hairdressing: a case study of a rapidly increasing business among women in urban Ghana, African Study Monographs 29: 83-94.

Olwig, M. F. and Gough, K. V. 2013. Basket weaving and social weaving: young Ghanaian artisans' mobilization of resources through mobility in times of climate change. Geoforum, 45: 168-177.

Palmer, R. 2007 Skills for work? From skills development to decent livelihoods in Ghana's rural informal economy, International Journal of Educational Development, 27: 397-420 
Palmer, R. 2009 Formalising the informal: Ghana's national apprenticeship programme, Journal of Vocational Education and Training, 61(1): 67-83

Patchett, M. 2017 Historical geographies of apprenticeship: rethinking and retracing craft conveyance over time and place. Journal of Historical Geography, 55: 30-43.

Parnell, S., \& Robinson, J. 2012 (Re) theorizing cities from the Global South: Looking beyond neoliberalism. Urban Geography, 33(4): 593-617.

Peil, M. 1970. The apprenticeship system in Accra. Africa, 40(2): 137-150.

Pini, B., Gulson, K.N., Kraftl, P. and Dufty-Jones, R. 2017 Critical geographies of education: an introduction, Geographical Research 55(1): 13-17

Porter, G., Hampshire, K., Abane, A., Tanle, A., Esia-Donkoh, K., Amoako-Sakyi, R.O., Agblorti, S. and Owusu, S.A. 2011 Mobility, education and livelihood trajectories for young people in rural Ghana: a gender perspective, Children's Geographies, 9(3-4): 395-410

Potts, D., 2008 The urban informal sector in sub-Saharan Africa: from bad to good (and back again), Development Southern Africa, 25(2): 151-167

Radcliffe, S. A. 2017 Decolonising geographical knowledges. Transactions of the Institute of British Geographers, 42(3): 329-333

Rigg, J. 2007 An everyday geography of the global South, Routledge, London.

Rolleston, C. 2011 Educational access and poverty reduction: The case of Ghana 1991-2006, International Journal of Educational Development, 31(4): 338-349

Sadlier, S.T. 2014 The tarpaulin and the tablecloth: cover and non-traditional education in traditional spaces of schooling. In Mills, S. and Kraftl, P. (eds) Informal education, childhood and youth, Palgrave Macmillan, London

Schraven, B., Hinz, A., Renaud, P., Rumke, C., Schommers, A. and Sikorski, A. 2013 Youth poverty in Accra: Managing urban livelihoods in informal apprenticeships, ILO, Geneva, Employment Sector Report No. 21

Smith, E. 2016 Apprenticeship: one concept, many facets. Journal of Education + Training, 58(6) https://doi.org/10.1108/ET-05-2016-0083

Smith, T. A., and Phillips, R. 2017 Informal education, its drivers and geographies: necessity and curiosity in Africa and the West. In: Abebe, T., Walters, J. and Skelton, T. (eds) Laboring and Learning, Geographies of Children and Young People Springer Nature, Singapore, 65-89

Vanderbeck, R.M. 2007 Intergenerational geographies: age relations, segregarion, and reengagements, Geography Compass, 1(2): 200-21

Wallaert-Pêtre, H. 2001 Learning how to make the right pots: Apprenticeship strategies and material culture, a case study in handmade pottery from Cameroon, Journal of Anthropological Research. 57: 471-493

Yankson, P. and Owusu, G. 2015 Youth entrepreneurship in auto spare parts sales and repair service in Accra, Ghana, Developing Country Studies 5(4): 84-97 


\section{Author biographies}

KATHERINE V. GOUGH is Professor of Human Geography in the School of Social Sciences, Loughborough University, UK. Email: k.v.gough@lboro.ac.uk Her research focusses on urban issues in the global South, with a particular interest in youth mobility and employment, housing and home, rural-urban dynamics, and longitudinal research.

THILDE LANGEVANG is Associate Professor in the Department of Management, Society and Communication, Copenhagen Business School, Denmark. Email: tla@msc.cbs.dk Her research focusses on youth, entrepreneurship and micro- and small-enterprises in Africa, exploring in particular entrepreneurship motivations, aspirations and skills acquisition.

PAUL W.K. YANKSON is Professor in the Department of Geography and Resource Development, University of Ghana. Email: pyankson@ug.edu.gh He is an urban planner interested in urban and regional development issues in Ghana, including governance and decentralisation, land and housing, rural-urban dynamics and youth employment.

GEORGE OWUSU is Professor in the Institute of Statistical, Social and Economic Research (ISSER) and Director of the Centre for Urban Management Studies (CUMS), University of Ghana. Email: gowusu@ug.edu.gh His research interests include urbanization and urban planning, urban crime and violence, urban youth enterprises and employment, decentralization and local government. 